原著

\title{
ハムスター実験的歯周疾患におけるビスホスフォネート （シマドロネート）による破骨細胞の変化
}

\author{
長谷川 直 樹 \\ 鶴見大学歯学部口腔病理学教室 (主任：菅原信一教授) \\ 〔受付: 平成 8 年 5 月 30 日, 受理 : 平成 8 年 12 月 2 日〕 \\ Effects bisphosphonate (cimadronate) \\ on osteoclasts in experimental periodontitis in hamsters
}

Naoki Hasegawa

Department of Oral Pathology, School of Dental Medicine, Tsurumi University

(Chief : Prof. Nobukazu Sugawara)

2-1-3, Tsurumi, Tsurumi-ku, Yokohama 230, Japan

(Received on May 30, 1996 ; Accepted on December 2, 1996)

Key words : bisphosphonate/alveolar bone loss/osteoclast/ruffled border / experimental periodontitis

\begin{abstract}
A new bisphosphonate, disodium dihydrogen (cycloheptylamino)-methylene-1, 1-bisphosphonate (cimadronate, YM175) inhibits alveolar bone loss in experimental periodontitis in hamsters. The purpose effects of cimadronate on the morphology and the function of osteoclasts were examined. Hamsters were fed a powdered high-carbohydrate diet, and ligated with silk sutures at the lower first molar (M1) to induce periodontitis. The alveolar bone loss was estimated by measurement of the area between the cementoenamel junction and the crest of alveolar bone at the M1 by radiograph. Animals were administered cimadronate subcutaneously at the dose of 0 (control), $0.03,0.1$ and $0.3 \mathrm{mg} / \mathrm{kg} \times 2$ times/week. The amount of the alveolar bone loss in the above groups (at the 4th week) was, $1.05 \pm 0.31,0.95 \pm 0.25,0.59 \pm 0.14$ and $0.68 \pm 0.14 \mathrm{~mm}^{2}$, respectively. The number of osteoclasts 3 -fold was higher in the 0.1 and $0.3 \mathrm{mg} / \mathrm{kg}$ cimadronate administered groups $(p<0.01)$, than the control at the 4 th day after the ligation with silk suture. Electronmicroscopic examinations, of the osteoclasts revealed the deficiency in ruffled border formation in the cimadronateadministered groups. These findings suggest that cimadronate affects the function of osteoclasts.

In conclusion, the inhibition of alveolar bone loss by cimadronate might be due to the dysfunction of osteoclasts, although they increased in number.
\end{abstract}

抄録：ビスホスフォネート新誘導体 disodium dihydrogen (cycloheptylamino)-methylene-1, 1-bisphosphonate (cimadronate, YM175) は八ムスター実験的歯周疾患において強い歯槽骨吸収抑制作用を示す。本実験 は cimadronate が破骨細胞の機能および形態に及ほす影響を調べることを目的とする。八ムス夕ーは蔗糖含有粉 末飼料で飼育するとともに，下顎第 1 臼歯 (M1) 歯頸部を手術用縫合絹系で結紮し，歯周疾患を起こさせた。歯 
槽骨吸収量は, M1 のエナメルーセメント境と䨑槽骨頂の間の面積を軟 X線撮影により算定した。cimadronate を 0 (対照)， $0.03 ， 0.1$ および $0.3 \mathrm{mg} / \mathrm{kg}$, 週 2 回皮下注射した。その結果, 結禁後 4 週目における各群の菌槽骨 吸収量はそれぞれ $1.05 \pm 0.31 ， 0.95 \pm 0.25,0.59 \pm 0.14$ および $0.68 \pm 0.14 \mathrm{~mm}^{2}$ を示し, cimadronate 投与によ り顕著に骨吸収が抑制された。組系結禁 4 日後における cimadronate 0.1 および $0.3 \mathrm{mg} / \mathrm{kg}$ 投与群の破骨細胞数 は, 対照群に比較して約 3 倍に増加した後, 徐々に減少した。電子顕微鏡による破骨細胞の観察では, 波状縁 (ruffled border) の不十分な形成が観察され，cimadronate が破骨細胞の機能を障害することが示唆された。

以上の結果から, cimadronate は破骨細胞数を増加させる一方で, 本細胞の機能を障害し, 結果的に骨吸収を 抑制するものと考えられた。

\section{緒言}

ビスホスフォネートはピロリン酸の類似化合物で, そ の骨格に P-C-P 結合を持ち, ホスファターゼによる水 解を受けにくい性質を示す。骨ハイドロキシアパタイト の吸収を抑制することから骨粗鬆症を始めとする種々の 骨疾患に応用され，すでにその一部は臨床で用いられて いる。近年, より有効な臨床効果をめざし, 種々のビス ホスフォネート化合物が, 開発されているが1-4), 骨吸収 抑制の作用機序はいまだ明確ではない。近年開発された ビスホスフォネートは初期のタイプのもの (1-hydroxythylidene-1, 1-bisphosphonic acid, etidronate) と比較 し 1000 10000 分の 1 の投与量で効果を示すものもあ り，単にハイドロキシアパタイトの水解を抑制すること のみでは骨吸収作用の機序を説明しきれず，ビスホス フォネートが破骨細胞に作用して骨吸収を抑制する可能 性が示唆されている

第 3 世代のビスホスフォネートの 1 つとして近年開発 されている disodium dihydrogen (cycloheptylamino)methylene-1, 1-bisphosphonate (cimadronate, YM175）は，アミノ基の水素原子の一方をシクロへプタ ン環に置換したアミノメタンビスホスフォネートであ り, 実験動物を用いた癌骨転移における骨吸収 ${ }^{9}$ や骨粗 㝆症モデル10)などに対して強い骨吸収抑制効果を発揮す ることが報告されている。この第 3 世代のビスホスフォ ネートはまた, 硬組織の石灰化阻害作用が強い etidronate $^{11,12)}$ に比べて, 石灰化阻害作用が少ない。近 年, これらを用いた歯槽骨吸収抑制作用の研究が歯学領 域でもなされている ${ }^{13-15)}$ 。岡本および筆者ら ${ }^{15)}$ は蔗糖含 有粉末飼料を用いたハムスター実験的歯周疾患におい て, cimadoronate が歯槽骨吸収抑制作用を示すことを 報告している。本実験は, cimadronate の歯槽骨吸収に 及浑す影響を調べる目的で, 八ムスターを蔗糖含有粉末 飼料で飼育し，さらに下顎第 1 臼歯 (M1) の歯頸部に絧 系を結紮し, 高度の炎症を引き起こした実験的歯周疾患 モデルを用い, 歯槽骨周辺の破骨細胞の変化について病
理組織学的に詳細に検討した。

\section{材料と方法}

\section{1. 実験動物}

実験には生後 6 週歯（平均体重 $90 \mathrm{~g}$ ）の雄性ゴールデ ンハムスター（日生研，長野）を使用した。ハムスター は金網の底敷を入れたプラスチック製ケージで飼育し， 水および飼料は自由捸取させ, 温度は $23^{\circ} \mathrm{C}$, 湿度 53〜 65\%を保ち, 明暗 12 時間サイクルの環境下で飼育し た。

\section{2. 実験的歯周疾患の作成法}

生後 8 週齢時のハムスターにペントバルビタールナト リウム (ネンブタール, 大日本製薬, 大阪) $20 \mathrm{mg} / \mathrm{kg}$ を 腹腔内注射し, 補助的にジエチルエーテルを吸入させて 麻酔し, M1 の歯頸部に隇菌済みの手術用縫合絹系 No. 4 (秋山製作所, 東京) を結紮した (Fig. 1)。Keyes の処 方した Diet\#2000 の蔗糖含有量を $56 \%$ から $30 \%$ に減少 させ, 減少分をコーンスターチで置き換えた粉末飼料(日 本クレア，東京）で飼育した（以下，便宜的に D2000 と 略す)。

\section{3. 薬物の投与量および投与方法}

Cimadronate は山之内製薬（東京）より供与された。 実験 1 は 20 匹のハムスターを 4 群 $(n=5)$ に分け, 生後 8 週齢より D 2000 で飼育すると同時に絧系を M1 に結 紮した。同時に第 1 群は生理食塩液のみ, 第 2,3 およ び 4 群は生理食塩液に溶解した cimadronate を 0.03 , 0.1 および $0.3 \mathrm{mg} / \mathrm{kg}$ を背部皮下に週 2 回注射した。結 絷後 4 週目にネンブタール麻酔下で, $0.1 \mathrm{M}$ カコジル酸

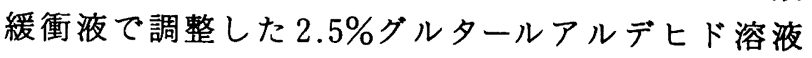
（pH7.4）を用い, 約 20 分間灌流固定した後, 下顎両側を 摘出し, 歯槽骨吸収量を測定した。

実験 2 は 36 匹の八ムスターを 3 群 $(n=3)$ に分け, 生 後 8 週鈴より D2000 で飼育すると同時に縫合系を M1 に結絷した。第 1 群は生理食塩液のみ, 第 2 および 3 群 
は生理食塩液に溶解した cimadronate 0.1 および 0.3 $\mathrm{mg} / \mathrm{kg}$, ハムスターの背部皮下に週 2 回注射した。結禁 後 2 日および 4 日目, 1 週および 2 週目に各群 3 匹ずつ ネンブタール麻酔下で実験 1 同様に灌流固定し, 下顎両 側を摘出し, 歯槽骨吸収量の測定, および病理組織学的 観察を行った。

\section{4. 歯槽骨吸収量の評価}

摘出した下䭭は $2.5 \%$ グルタールアルデヒド溶液で $4^{\circ} \mathrm{C}$ で再固定後, 軟 X線撮影をした。撮影装置は Softex CSM-2（ソフテックス，東京）を用い，撮影条件は二次 電圧 $90 \mathrm{kV}, 3 \mathrm{~mA} ， 7$ 秒間露出した。用いたフィルムは Softex film FR (富士フィルム), Rendol (富士フィル ム）にて $20^{\circ} \mathrm{C}, 4$ 分間現像し, Fuji fix（富士フィルム） にて $20^{\circ} \mathrm{C}, 6$ 分間定着し, 水洗, 乾燥した。軟 $X$ 線写真 はイメージカメラ (HQ-1000M, Nikon, 東京) を用いて 画像処理装置 (LUZEX3, Nikon，東京) に画像を取り込 み, Figure 1 に示すように, M1 近心のエナメルセメン 卜境と歯槽骨頂間の面積を計測し，歯槽骨吸収量とした。

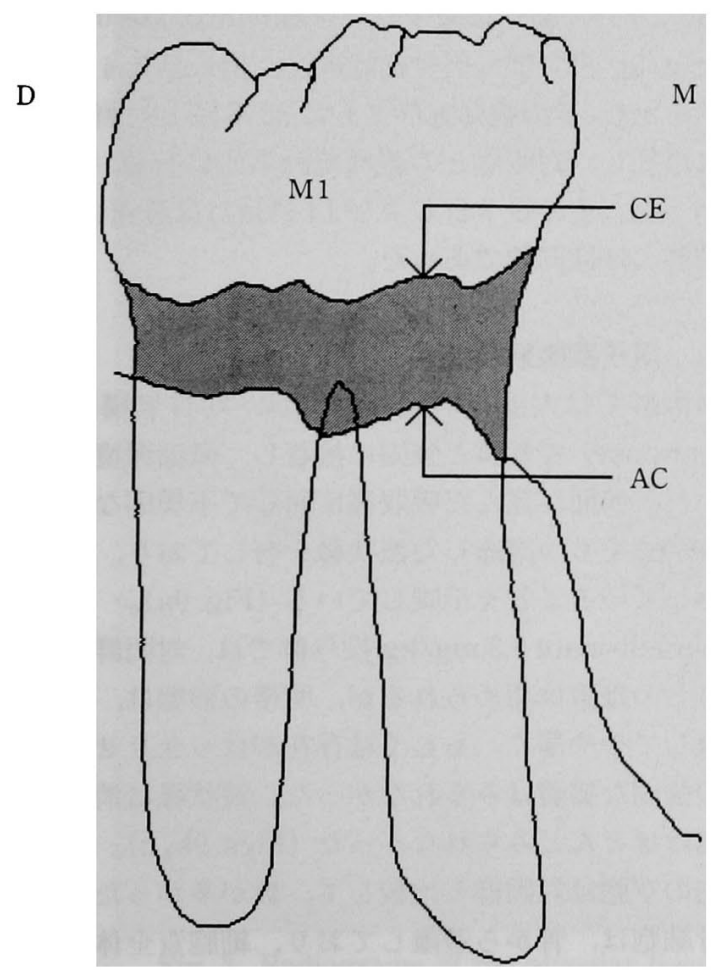

Fig. 1 Measurement of the area for alveolar bone loss at the lower first molar.

$\mathrm{CE}:$ cementoenamel junction, $\mathrm{AC}:$ crest of alveolar bone, M1 : lower first molar, M : medial, D : distal

\section{5. 病理組織学的観察}

1) 光学顕微鏡的観察

摘出した下顎は, $2.5 \%$ グルタールアルデヒド溶液にて $4{ }^{\circ} \mathrm{C} て ゙$ 再固定した。次いで 10\% EDTA-2Na（pH7.4）を 用いて $4{ }^{\circ} \mathrm{C} て ゙$ 脱灰し，パラフィン包埋後, M1 近心根根 尖を含むように，近遠心方向に切り出し，厚さ $3 \mu \mathrm{m}$ の 連続切片を作成し，ヘマトキシリンーエオジン染色 (H. E. 染色）した。また，破骨細胞を観察するために，アゾ 色素法 ${ }^{16 \sim 18)}$ による酸性ホスファターゼ染色を施し, 光学 顕微鏡観察に供した。酸性ホスファターゼ染色は 100 $\mathrm{mM}$ 酢酸緩衝液（pH5.0）中に基質として $1.25 \mathrm{mg} / \mathrm{m} l$ の naphthol AS-BI phosphonic acid (Sigma, U. S. A.) および発色剤として $2 \mu \mathrm{g} / \mathrm{m} l$ パラロザニリン (Sigma, U. S. A.) を含む液中で約 15 分間反応させ発色させた。

破骨細胞数は Figure 2 に示すように，歯根を通る M1 近遠心面で $1.8 \times 2.5 \mathrm{~mm}^{2}$ の範囲で面積を限定し, 顕微鏡 下で計数した。

2 ) 電子顕微鏡的観察

脱灰した組織は, M1 の近心根根尖を含むように, 近

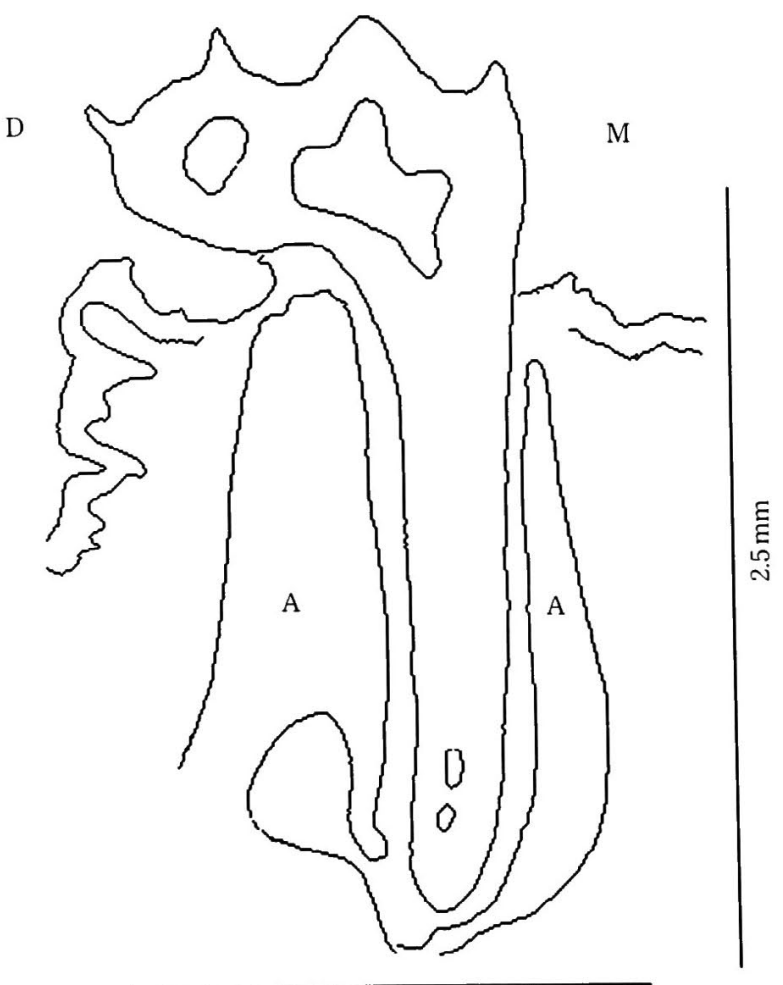

$1.8 \mathrm{~mm}$

Fig. 2 Measurement of the area for counting of the number of osteoclast at the lower first molar.

A : alveolar bone, $\mathrm{M}:$ medial, $\mathrm{D}$ : distal. 
遠心方向に切り出し，さらに歯頸部，歯根中央部，根尖 部に 3 分割した後, $2.0 \%$ オスミウム酸で後固定し, 通法 に従って脱水，置換，Epon812 に包埋した。3 分割した 組織は光学顕微鏡の観察により, 特に破骨細胞の増加し ていた歯槽骨骨頂部位をウルトラミクロトーム (ULTRACUT N, 日製産業, 東京) を用い, 超薄切片 を作成した。超薄切片は酢酸ウランとクエン酸鉛による 二重染色を施し, 透過型電子顕微鏡 (JEM-1200EX II, 日本電子，東京）にて観察した。

\section{6. 統計学的考察}

対照群および実験各群における歯槽骨吸収量および破 骨細胞数の平均值の差の検定は student's t-test を用い た。

\section{結＼cjkstart果}

\section{Cimadronate 投与後の歯槽骨吸収抑制作用}

Figure 3 は実験 1 における M1 周辺部の結紮後 4 週 目の軟 $\mathrm{X}$ 線撮影像を示す。生理食塩液のみを投与した対 照群では，歯頸部結紮部位および根分岐部に到る強い骨 吸収が認められた（Fig. 3a）。一方, cimadronate の投与 により歯槽骨吸収は抑制された。その吸収量は投与量を 増加するに従い，用量依存的に抑制された（Figs. 3b〜 d)。 cimadronate を $0.1 \mathrm{mg} / \mathrm{kg}$ 投与した群 (Fig. 3c) で は， $0.3 \mathrm{mg} / \mathrm{kg}$ 投与群 (Fig. 3d) とほほ同等の強い抑制 効果が認められ, 対照群と両群との差は統計学的に有意 であった $(\mathrm{p}<0.01)$ (Fig. 4)。

Figure 5 は実験 2 における結禁後 1 週および 2 週目 の骨吸収量を示す。cimadronate の投与群の骨吸収は結 禁後 1 週目は用量依存的に抑制され，骨吸収の進行を阻 止した。結紮後， 2 週目の cimadronate 0.1 および 0.3 $\mathrm{mg} / \mathrm{kg}$ 投与群では, ほほ同程度の強い骨吸収抑制効果が 認められ, 対照群と比較し, その差は統計学的に有意で あった $(\mathrm{p}<0.05)$ 。

\section{Cimadronate 投与後の歯周組織像}

手術用縫合組系結禁後 4 日目の対照群では絹系に細菌 が多数付着し，その周囲および歯肉に多数の好中球が浸 潤し，歯肉内縁上皮には潰湯形成がみられた。潰瘍面下 の粘膜固有層には好中球を主とした炎症細胞の浸潤と毛 細血管の増殖，線維性組織の破壊がみられた（Fig. 6a）。 cimadronate $0.3 \mathrm{mg} / \mathrm{kg}$ 投与群では潰湯形成は減少し, 歯肉内縁上皮は一部修復されたが, 炎症程度は対照群と ほほ同じであった。上皮下の好中球などの炎症細胞浸潤
は少なく, 毛細血管の増殖がみられ, 組系結紮による歯 肉縁の後退がみられた (Fig. 6b)。

組系結热後 2 週目の対照群では近心側および遠心側の 歯肉内縁上皮は，一部修復されているが，上皮内は空胞 変性がみられ，好中球が浸潤していた。粘膜固有層では 少量の好中球浸潤が上皮直下に限局し, 軽度の結合組織 線維配列の乱れと毛細血管の増殖がみられたが，炎症細 胞の歯間水平線維への波及は認められなかった（Fig. 6c)。cimadronate 0.1 および $0.3 \mathrm{mg} / \mathrm{kg}$ 投与した群で は, いずれも軟組織の結合組織線維配列の乱れがみられ るが, 対照群に比べて歯槽骨吸収の程度は軽度であった (Fig. 4d)。

\section{3、破骨細胞染色像および破骨細胞数}

絹系結禁後 4 日目の酸性ホスファターゼ染色による破 骨細胞の所見は, 対照群で歯槽骨頂周辺に多いのに対し (Fig. 7a), cimadronate 0.1 および $0.3 \mathrm{mg} / \mathrm{kg}$ 投与群で は歯槽骨表面全体にみられた（Figs. 7b, c)。

対照群の Figure 2 に示す単位面積あたりの破骨細胞 数は, Figure 8 に示すごとく絹系結禁後徐々に増加し, 4 日目に $1 \mathrm{~mm}^{2}$ 当たり 11.9 個と最高値を示した。以後 7 日，14 日と徐々に減少した。cimadronate 0.1 および $0.3 \mathrm{mg} / \mathrm{kg}$ 投与群の破骨細胞数は, 絹系結紫 4 日後に最 高值を示し,その数は両群ともに 30.6 個と対照群の約 3 倍に増加し, 対照群との差は統計学的に有意 $(\mathrm{p}<0.01)$ であった。その後 7 日および 14 日目には急速に減少し, 対照群とほほ同数であった。

\section{4. 電子顕微鏡的観察}

対照群では大部分の破骨細胞が，均質無構造の明帯 (clear zone) で骨質と強固に接着し, 微細環境を形成し ていた。表面が寉んだ吸収窩に面して不規則な細胞突起 (微絨毛)をもつ発達した波状縁を有しており，骨吸収が 進行していることを示唆している (Fig. 9a)。

Cimadronate $0.3 \mathrm{mg} / \mathrm{kg}$ 投与群では, 対照群と同様に 骨質との接着は認められるが，明帯の形態は，対照群と 比較してやや薄く，もしくは存在がはっきりせず，骨質 との強固な接着はみられなかった。波状緑は消失し, 吸 収窝はほとんどみられなかった (Figs. 9b, c)。また細胞 質内の空胞は対照群と比較して, 数が多かった。一部の 破骨細胞は, 骨から遊離しており, 細胞質全体に空胞が 散在していた（Fig. 9d）。核の多くはほほ円形ないし棈円 形を示していたが，対照群同様に変形しているものも認 められた。粗面小胞体, ミトコンドリア, ゴルジ装置な どの細胞内小器官は対照群と同様で, 数や形態の特異的 


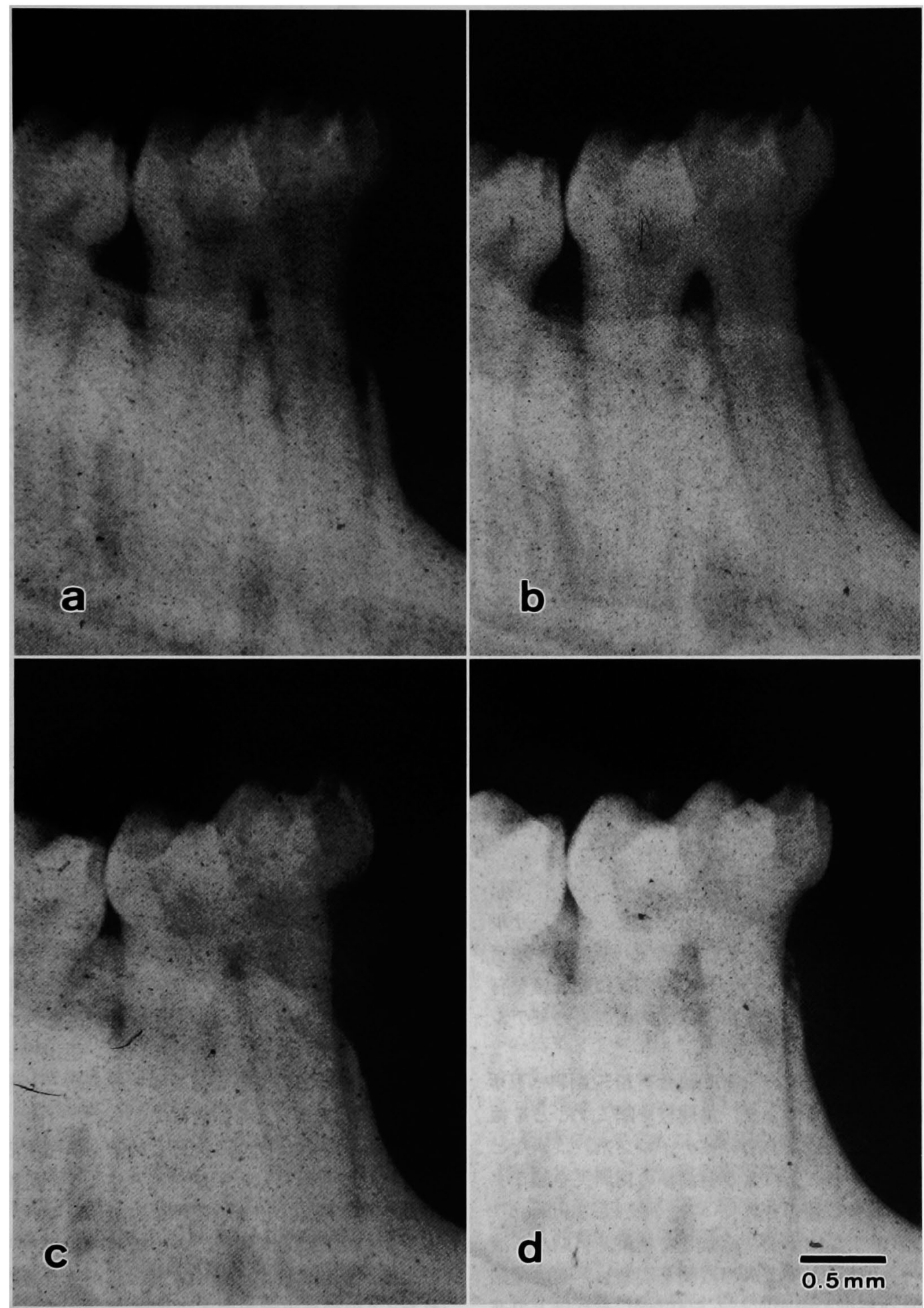

Fig. 3 Radiograms of the alveolar bone at the lower first molar in hamsters. Hamsters were received cimadronate at the dose of 0 (a), 0.03 (b), 0.1 (c), and 0.3 (d) $\mathrm{mg} / \mathrm{kg}, 2$ times a week, at the 4 th week after ligation. 


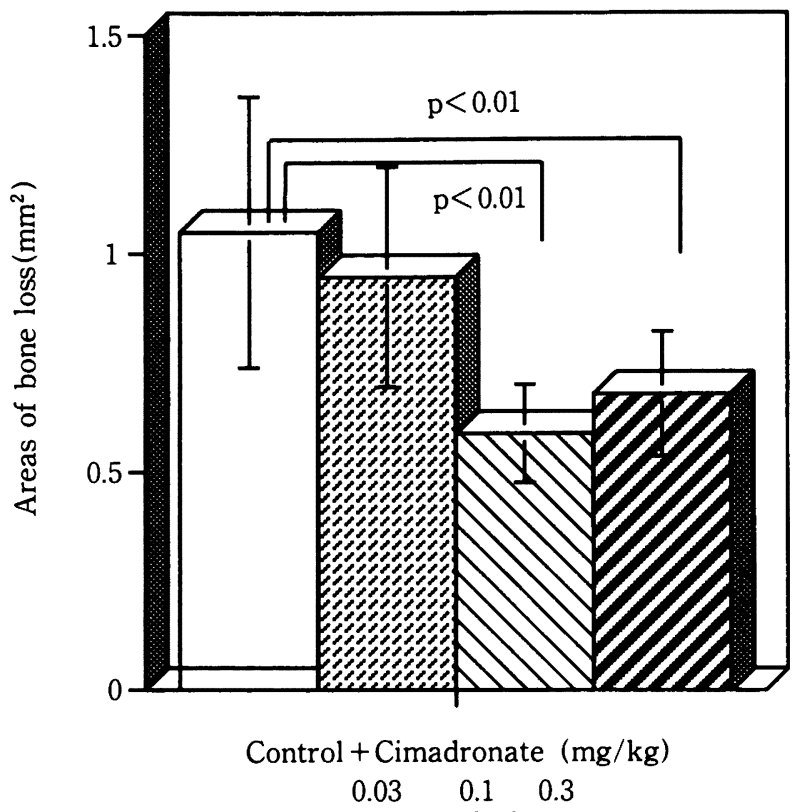

Fig. 4 Inhibitory effect of cimadronate on the alveolar bone lose at the 4 th week after ligation. The alveolar bone losses in the cimadronate administered groups (except $0.03 \mathrm{mg} / \mathrm{kg}$ ) were significantly inhibited $(p<0.01)$, as compared with the control. $(n=5$, mean \pm S. D.)

変化は認められなかった（Figs. 9b〜9d)。

\section{考察}

実験的歯周炎は，彗歯類をはじめとして，イヌ，サル 等の動物が多く使用されている。䍮歯類, 特にゴールデ ンハムスターは煩袋を有するなどの特別な口腔環境を有 し，歯周炎に罹患しやすく，広く実験的歯周炎のモデル に使用されている。

Keyes ら $\left.{ }^{19}\right)$ はムスターを蔗糖含有粉末飼料（D\# 2000）で飼育することにより，歯周炎を起こすことを報 告している。また, 絹系あるいはナイロン系, ゴムなど を歯頸部へ結紮することにより琶歯類の歯周炎を起こす 実験が以前より多数報告されている。例えば, Johnson ${ }^{20)}$

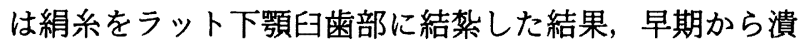
晹の形成，好中球の上皮下への浸潤を観察し，実験開始 後 27 日目には軽度の骨吸収がみられたが, それ以上の進 行はしないことを報告している。吉成は21), ラットの上顎 臼歯歯間部にナイロン系を挿入した歯周炎モデルでは軽 度の炎症細胞浸潤が認められ， 7 週以降に歯間水平線維 の軽度の乱れを観察し, 歯槽骨の吸収が経時的に進むこ

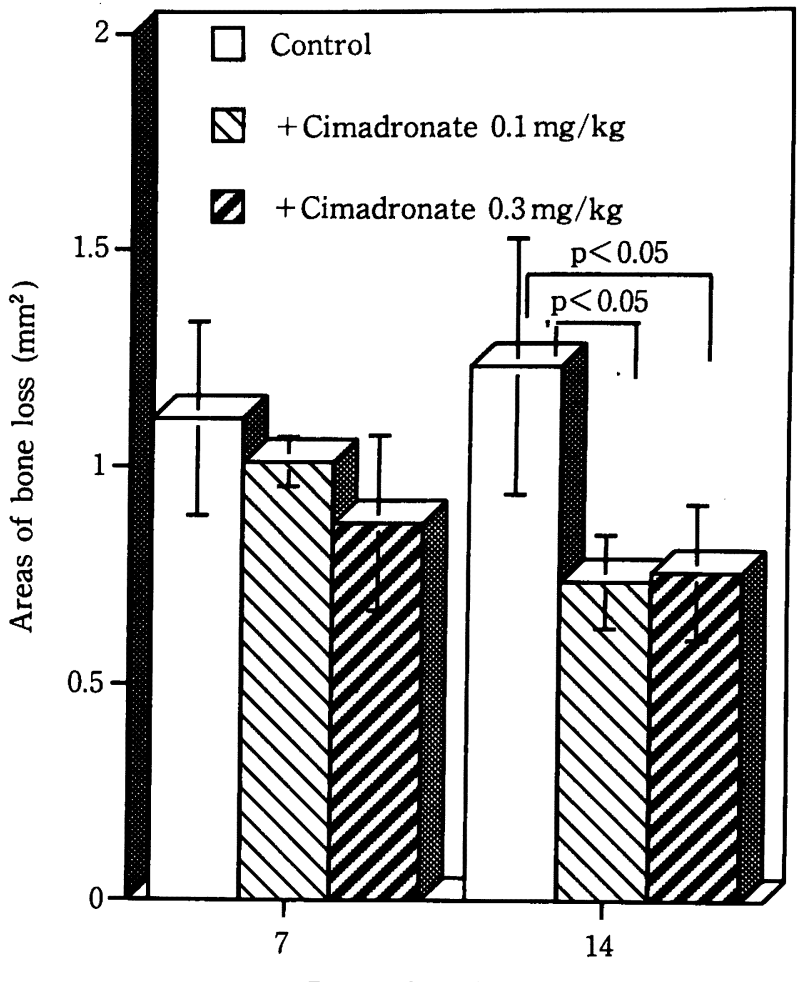

Days after ligation

Fig. 5 Inhibitory effect of cimadronate on the alveolar bone lose at the first and second weeks after ligation. The alveolar bone losses at the 2 nd weeks after ligation in the 0.1 and $0.3 \mathrm{mg} / \mathrm{kg}$ of cimadronate administered groups were significantly inhibited $(p<0.01) .(n=3$, mean \pm S. D. $)$

とを報告している。下野ら ${ }^{22)}$ は無菌ラットと普通飼育 ラットを用いて，矯正用ゴムを歯間部に挿入して歯周炎 を作り，機械的な刺激と, プラークによる刺激が歯周炎 の進行に寄与するかを調べた。その結果, 無菌ラット群 では，炎症は表層に限局し，機械的刺激のみでは骨吸収 は認められないことを報告している。色川深も同様に歯 周炎惹起には歯の移動などの機械的刺激とともに細菌感 染が必要であることを報告している。

今回の実験は, D2000 飼育と結热を併用することによ り，粘膜固有層には好中球を主とした炎症細胞の浸潤と 毛細血管の増殖, 線維性組織の破壊がみられ, 当教室が

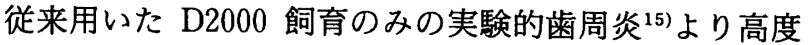
の炎症が惹起され，1週〜 4 週にわたり骨吸収が観察さ れた。この様な実験条件下で cimadronate の歯槽骨吸収 に及ほす効果を軟X線撮影により調べると，実験 1 およ び 2 で観察されたように, 結禁後 1 週で既に骨吸収抑制 効果が現れ， 2 週および 4 週目には，統計学的に有意の 差を示して抑制していた（Figs. 4, 5)。 cimadronate 0.3 


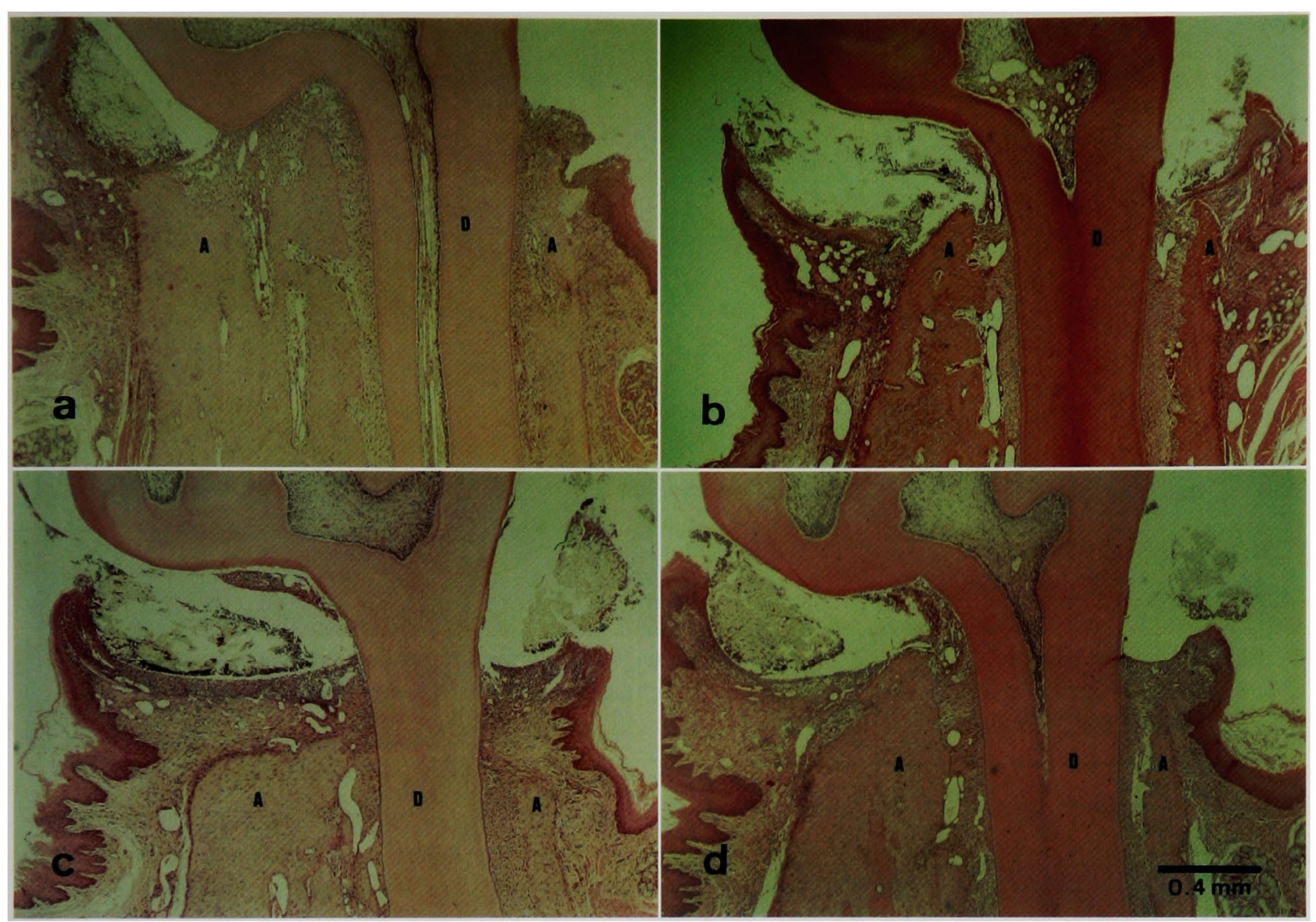

Fig. 6 Hematoxylin-Eosin stainings of the sagittal section of the lower first molar in hamsters.

Hamsters were received cimadronate at the dose of $0(\mathrm{a}, \mathrm{c})$, and $0.3(\mathrm{~b}, \mathrm{~d}) \mathrm{mg} / \mathrm{kg}$, at the 4 th day $(\mathrm{a}, \mathrm{b})$ and the $2 \mathrm{nd}$ week (c, d) after ligation.

A : alveolar bone, D : dentine

$\mathrm{mg} / \mathrm{kg}$ 投与群では骨の露出がみられた (Figs. 6b, d)。 このことは, cimadronate が骨吸収に対して効果的に働 くが, 軟組織の炎症とそれに引き続いて起こる軟組織の 破壊に対しては効果を示さないことを示唆している。逆 に言うと, 強い炎症が起きているにもかかわらず cimadronate が骨吸収を抑制するものと考えられる。

ビスホスフォネートは破骨細胞数を増加あるいは減少 させるという相反する報告がある。Kodama ら”は, 遺伝 的に破骨細胞形成不全のみられる大理石骨病 (op/op) マウスを用い, M-CSF を投与し, 破骨細胞の誘導を脛 骨において観察した。M-CSF 投与後 4 日以降に cimadronate を投与した場合, 破骨細胞は減少したが， MCSF 投与 3 日以内の cimadronate 投与では破骨細胞の 減少はみられないことを報告している。すなわち cimadronate は前破骨細胞から破骨細胞への形成を抑制する ことなく, 成熟した破骨細胞に殺細胞的に働き，その結
果, 破骨細胞が減少することを考察している。一方, Endo ら ${ }^{6} は$ は, マウスを用いた実験で, alendronate がヒスチジ ン脱炭酸酵素活性を誘導し，ヒスタミンを増加させ，そ の結果マクロファージ, 単核細胞および破骨細胞の形成 を促進することを報告している。Aida ら ${ }^{24)}$ は， in vitro の実験で, etidronate がマクロファージなどからの IL1 遊離を促進することを報告しており，in vivo でもビス ホスフォネートが免疫担当細胞などに作用し, サイトカ イン等を介して前破骨細胞に作用し, 破骨細胞への分化 を誘導する可能性が考えられる。

本実験では, cimadronate 投与により結禁後 4 日目に 破骨細胞数が最高值となり対照群に比べて約 3 倍に増加 したが, その後対照群と同様に減少した (Figs. 7, 8)。こ のことは, 他のビスホスフォネートと同様, 前破骨細胞 から破骨細胞への分化成熟過程を cimadronate が促進 し, 破骨細胞数を増加させたものと考えられる。その後 


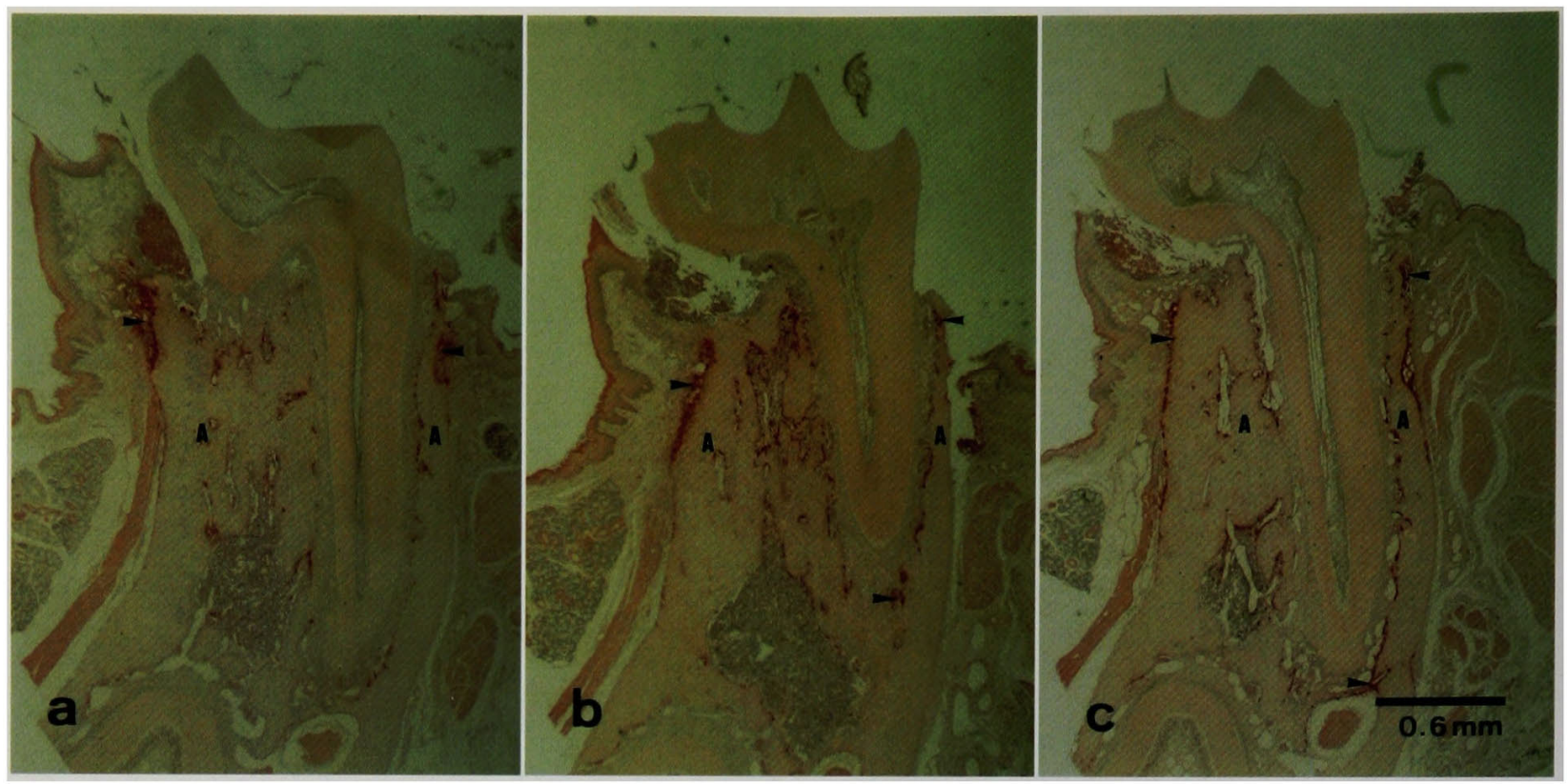

Fig. 7 Acid-phosphatase stainings of the sagittal section of the lower first molars. Hamsters were received cimadronate at the dose of 0 (a), 0.1 (b), and 0.3 (c) $\mathrm{mg} / \mathrm{kg}$, at the 4 th day after ligation. A : alveolar bone, arrow head : osteoclast

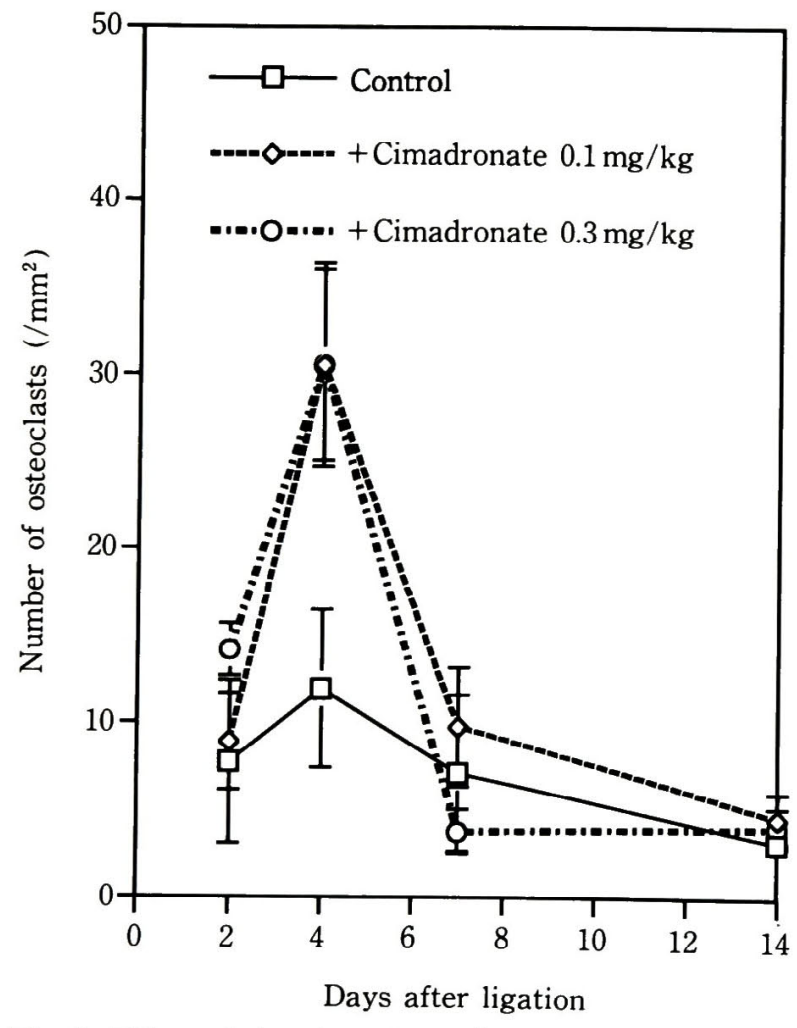

Fig. 8 Effect of cimadronate on the number of the osteoclast. The number of osteoclast in the cimadronate administered groups $(0.1$ and $0.3 \mathrm{mg} / \mathrm{kg})$ increased 3 -fold $(\mathrm{p}<0.01)$ as compared to the control at the 4 th day after ligation. $(n=3$, mean \pm S. D. $)$
ビスホスフォネートの長期的な作用により，アポトーシ スの誘導など破骨細胞に対し殺細胞的に働き ${ }^{25,26)}$, 細胞 数は次第に減少したことが考えられる。このことは薬物 の投与期間と関連し, 筆者らが以前 D2000 のみを用いた 実験的歯周炎で得られた cimadronate によって破骨細 胞が減少した結果 ${ }^{15)}$ と, 今回 1 週〜 4 週で観察された結 果は一致するものと考えられる。

対照群における破骨細胞の分布は，歯槽骨骨頂部に多 く観察されたが，これは結禁に伴う炎症部位に近いこと によるものと考えられる。一方, 実験群では, 薬物の影 響が, 炎症による破骨細胞の増加よりも多いため, その 結果, 歯槽骨全体に破骨細胞が分布したと考えられる。

ビスホスフォネートは, 歯槽骨のみではなく, 全身的 に骨の吸収および添加の起きる部位で作用すると考えら れ，破骨細胞の形態の変化も歯槽骨同様に起きているも のと考えられる。

前骨芽細胞と破骨細胞は融合することが知られてお り，両細胞の間に骨形成あるいは骨吸収に関する密接な 情報の交換が行われていると考えられる27)。Sahni ら ${ }^{28)}$ はビスホスフォネートが骨芽細胞に作用し, 何らかの作 用物質を介して破骨細胞の骨吸収作用を抑制することを in vitro の実験で報告している。

骨吸収が効率良く行われるように破骨細胞の明帯は外 界を遮断し, 微細環境を形成する。波状縁の微絨毛表面 


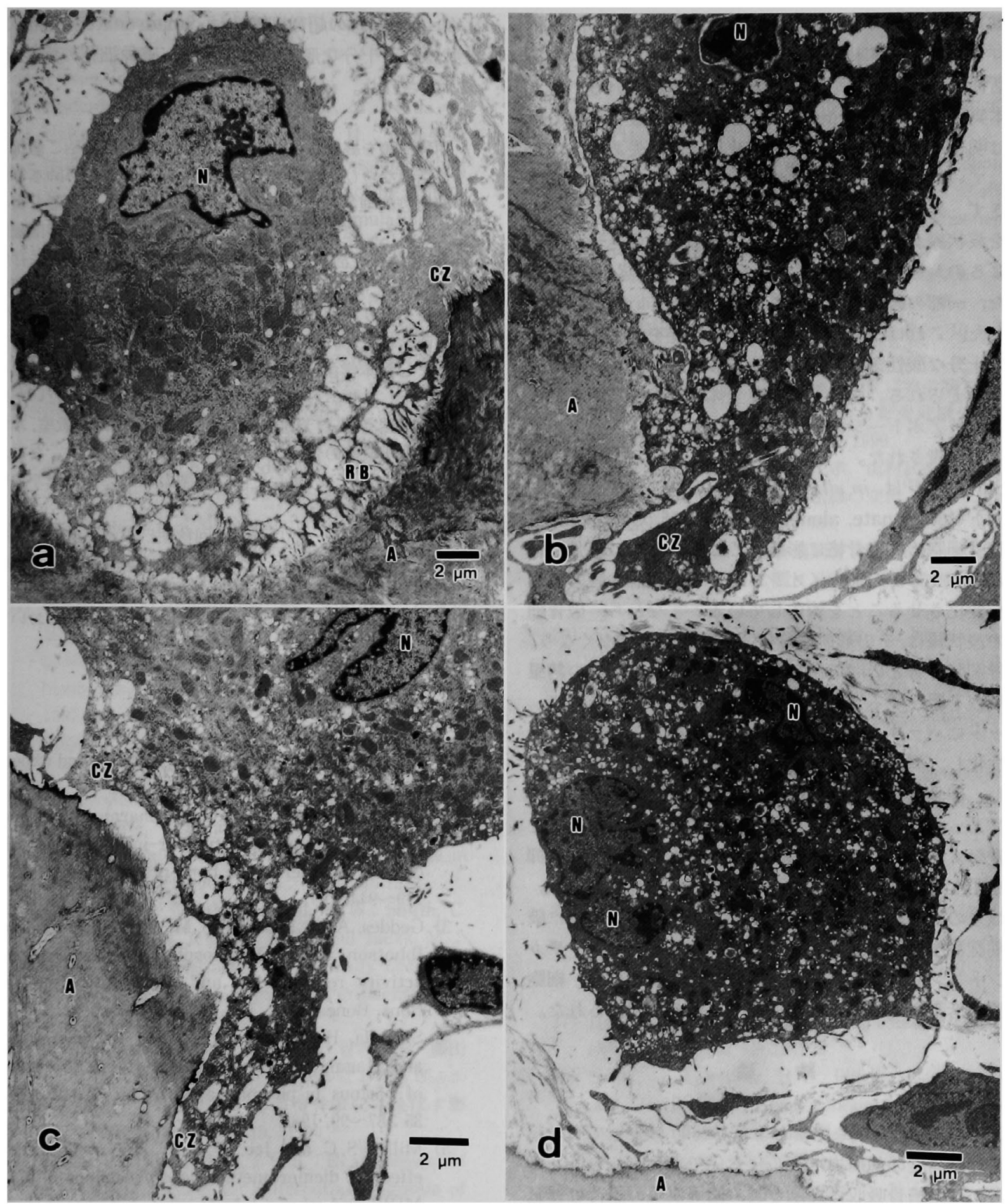

Fig. 9 Effect of cimadronate on the ultrastructure of osteoclast. Upon electron microscopic examinations, the osteoclasts were dificient in ruffled border formation ( $b$ and $c$ ), and some osteoclast was dissociated from bone (d), in the $0.3 \mathrm{mg} / \mathrm{kg}$ cimadronate administered groups, which were not observed in the control (a). RB : ruffled border, $\mathrm{CZ}$ : clear zone, $\mathrm{N}$ : nuclei, A : alveolar bone 
で働くプロトンポンプにより微細環境は酸性化し，ハイ ドロキシアパタイトを溶解するとともにリソソーム䣼素 を活性化して骨吸収を行うものと考えられている ${ }^{29,30) 。 ~}$

本実験において, cimadronate 投与群の破骨細胞の形 態は明帯が明瞭でなく，さらに波状緑が消失あるいは変 形していた。このことが破骨細胞が薬物作用により成熟 できず，発達した波状縁をもたないことによるのか，薬 物を波状縁から吸収した後にその形態を変化させたこと によるのかは明らかではない。しかし, 吸収窩が少なく, また，一部の破骨細胞は骨質から遊離しているものもみ られた。これは本薬片が破骨細胞の機能を低下させたた め, 十分な酸性条件の微細環境を形成できなかった可能 性が考えられる。また, 細胞質全体に空胞が観察された ことは, アポトーシスのような細胞死に至る前兆である ことも示唆された。

Sato ら ${ }^{31,32}$ は, in vitro の実験で, 3 種のビスホスフォ ネート (etidronate, alendronate および pamidronate) が破骨細胞の細胞骨格に影響すること, さらに破骨細胞 のカルシウムその他のイオンに対する波状縁の膜の透過 性を変化させることを報告している。すなわち, 破骨細 胞の波状縁は, その形態を維持することができなくなり， 破骨細胞と骨との間で微細環境を形成できず，その結果 骨吸収を阻止すると考察している。Sato ら ${ }^{321}$ はさらに, ラットにパラサイロイドホルモンを投与して破骨細胞を 活性化し, 同時に $0.4 \mathrm{mg} / \mathrm{kg}$ の alendronate を皮下投 与し, 破骨細胞の超微細構造を観察した結果, 明帯は明 瞭であったにも関わらず，波状縁は消失していたことを 報告している。このように波状緑を変化させ，骨吸収抑 制を示す薬物としてカルシトニンが報告されている33)。

以上のことから, 歯周組織において cimadronate は破 骨細胞数を増加させるが, 他のビスホスフォネートやカ ルシトニンと同様に破骨細胞の波状縁を変化させ, 細胞 機能を低下させ，骨吸収を抑制するものと考えられた。

\section{結＼cjkstart論}

1. 手術用縫合絹系結紮およびD2000によって引き起 こされた高度の歯周炎モデルにおいて, cimadronate 投 与により歯槽骨吸収は抑制され, 歯周疾患の進行は遅延 した。

2. 対照群の破骨細胞数は, 絹系結禁後 4 日目に最高 になり,その後徐々に減少した。cimadronate 投与群の 破骨細胞数は, 絹系結紮後 4 日目に対照群と比較し, 約 3 倍に増加したが, その後は対照群と同様に, 徐々に減 少した。
3. 破骨細胞の超微細構造は cimadronate 投与群では 波状緑の不十分な形成が観察され, 破骨細胞の機能低下 が示唆された。

謝辞：稿を終えるに臨み，本研究に対して終始ご愁篤な るご指導ならびに本論文のご校閲を賜りました恩師本学歯 学部口腔病理学教室 菅原信一教授に深甚なる謝意を表し ます。また，想切なるご校閲を賜りました本学歯学部細菌 学教室 藤田 浩教授ならびに本学歯学部第二歯科保存学 教室 新井 高教授に心より深謝いたします。さらに本研究 遂行にあたり多大なご指導, ご教示を賜りました本学歯学 部細菌学教室 岡本公彰講師, また, 終始ご指導, ご助言下 さいました本学歯学部細菌学教室 前田伸子助教授に厚く 感謝いたします。最後に，ご援助，ご助言をいただいた本 学中央電顕室 島貫芳雄先生ならびに本学細菌学教室, 本学 口腔病理学教室の皆様のご協力に謝意を表します。なお， 薬物をご供与下さいました山之内製薬株式会社に厚くお礼 を申し上げます。

本論文の要旨の一部は, 第 37 回秋期日本歯周病学会学術 大会(1994 年 10 月 7 日, 大阪), 第 36 回歯科基碳医学会総 会 (1994 年 10 月 18 日, 大阪) および第 73 回国際歯科研究 学会 (IADR：1995 年 6 月 28 日, シンガポール) において 発表した。

\section{文献}

1) Fleisch, H. : Bisphosphonates-History and experimental basis. Bone $8: 23 \sim 28,1987$.

2) Fleisch, H.: Bisphosphonates pharmacology and use in the treatment of tumour-induced hypercal. caemic and metastatic bone disease. Drugs 42 : 919 944, 1991.

3) Geddes, A. D., D'Souza, S. M., Ebetino, F. H. and Ibbotson, K. J. : Bisphosphonates : structureactivity relationships and therapeutic implications. Bone Miner. Res. $8: 265 \sim 306,1994$.

4) Shinoda, H., Adamek, G., Felix, R., Schenk, R. and Hagan, P. : Structure-activity relationships of various bisphosphonates. Calcif. Tissue. Int. $35: 87 \sim 99,1983$.

5) Miller, S. C. and Jee, W. S. S. : The comparative effect of dichloromethylene diphosphonate $\left(\mathrm{CL}_{2}\right.$ MDP) and ethane-1-hydroxy-1, 1-diphosphonate (EHDP) on growth and modeling of the rat tibia. Calcif. Tiss. Res. $23: 207 \sim 214,1977$.

6) Endo, Y., Nakamura, M., Kikuchi, T., Shinoda, H., Takeda, Y., Nitta, Y. and Kumagai, K. : Aminoalkyl-bisphosphonates, potent inhibitors of bone resorption, induced a prolonged stimulation 
of histamine synthesis and increase macrophages, granulocytes, and osteoclasts in vivo. Calcif. Tissue. Int. 52:248〜254, 1993.

7) Kodama, H., Yamasaki, A., Abe, M., Niida, S., Hakeda, Y. and Kawashima, H. : Transient recruitment of osteoclasts and expression of their function in osteopetrotic (op/op) mice by a single injection of macrophage colony-stimulating factor. J. Bone Miner.Res. 8: 45 50, 1993.

8) Flanagan, A. M. and Chambers, T. J. : Dichloromethyle-nebisphosphonate $\left(\mathrm{Cl}_{2} \mathrm{MBP}\right)$ inhibits bone resorption through injury to osteoclasts that resorb $\mathrm{Cl}_{2} \mathrm{MBP}$-coated bone. Bone Mineral. 6 : 33 $\sim 43,1989$

9) Nemoto, R., Nishijima, Y., Uchida, K. and Koiso, K. : Inhibition by a new bisphosphonate (YM175) of bone resorption induced by the MBT- 2 tumour of mice. Br. J. Cancer $67:$ 893 897, 1993.

10) Kawashima, H. : Mechanism and clinical evaluation of bisphosphonate. Clinical Calcium $3: 1324$ 〜1326, 1993.

11) Fouda, N., Caracatsanis, M., Alatlikut, I. and Hammarstrom, L. : Mineralization disturbances of the developing rat molar induced by mono-and bisphosphonates. J. Biol. Buccale 19: 106 115, 1991.

12）田谷雄二, 須賀昭一：HEBP の長期経口投与による エナメル質形成異常. 歯基礎誌 $31 ： 560 ＼mathrm{~ 594, ~} 1992$.

13) Brunsvold, M. A., Chaves, E. S., Kornman, K. S., Aufdemorte, T. B. and Wood, R. : Effects of a bisphosphonate on experimental periodontitis in monkeys. J. Periodontol. 63: 825 830, 1992.

14) Reddy, M. S., Weatherford, III, T. W., Smith, C. A., West, B. D., Jeffcoat, M. K. and Jacks, M. : Alendronate treatment of naturally-occurring periodontitis in beagle dogs. J. Periodontol. 6 : 211 217, 1995.

15）岡本公彰，長谷川直樹，前田伸子，菅原信一，藤田 浩：ハムスター実験的歯周炎モデルにおけるビスホ スフォネート（YM175）の歯槽骨吸収に及ほす影 響。歯基礎誌 $36: 510 \sim 519,1994$.

16) Katayama, I. and Yang, J. P. S. : Reassessment of a cytochemical test for differential diagnosis of leukemic reticuloendotheliosis. Am. J. Clin. Pathol. $68: 268 \sim 272,1977$.

17) Burstone, M. S. : Histochemical demonstration of acid phosphatase activity in osteoclasts. J. Histochem. Cytochem. $7: 39 \sim 41,1959$.

18) Koide, M., Suda, S., Saitoh, S., Ofuji, Y., Suzuki,
T., Yoshie, H., Takai, M., Ono, Y., Taniguchi, Y. and Hara, K. : In vivo administration of IL-1 $\beta$ accelerates silk ligature-induced alveolar bone resorption in rats. J. Oral. Pathol. Med. 24: 420 $\sim 434,1995$.

19) Keyes, P. H. and Jordan, H. V.: Periodontal lesions in the syrian hamster-III, Findings related to an infectious and transmissible component. Archs. Oral. Biol. 9 : 377-400, 1964.

20) Johnson, I. H. : Effects of local irritation and dextran sulphate administration on the periodontium of the rat. J. Periodont. Res. 10 : 322 〜345, 1975.

21）吉成伸夫：ラットの実験的歯周病変におよほす長期 間のメソトレキセート投与による好中球減少の影 響. 愛院大歯誌 $28 ： 345 \sim 366,1990$.

22）下野正基, 浜田義信, 井上 孝, 山村武夫, 古賀正 忠：咬合性外傷による歯周組織の変化. The Quintessence 5：1044〜1055, 1986.

23）色川俊則：無菌および普通飼育ラットを用いた歯周 組織の損傷と修復に関する研究. 日歯周誌 20 : 233〜248, 1980 .

24) Aida, Y., Toda, Y., Shimakoshi, Y., Yamada, K. and Aono, M.: Effects of disodium ethane-1hydroxy-1, 1-diphosphonate (EHDP) on interleukin 1 production by macrophages. Microbiol. Immunol. 30 : 1199 1206, 1986.

25) Hughes, D. E., Wright, K. r., UY, H. L., Sasaki, A., Yoneda, T., Roodman, G. D., Mundy, G. R. and Boyce, B. F.: Bisphosphonates promote apoptosis in murine osteoclasts in vitro and in vivo. J. Bone Miner. Res. 10 : 1478 1487, 1995.

26) Kameda, T., Ishikawa, H. and Tsutsui, T. : Detection and characterization of apoptosis in osteoclasts in vitro. Biochem. Biophys. Res. $207: 753$ $\sim 760,1995$.

27) Hanaoka, H. : The origin of the osteoclast. Clin. Orthop. 145:252 263, 1979.

28) Sahni, M., Guenther, H. L., Flisch, H., Collin, P. and Martin, T. J. : Bisphosphonates act rat bone resorption through the mediation of osteoblasts. J. Clin. Invest. $91: 2004 \sim 2011,1993$.

29) Marks Jr., S. C. and Popoff, S. N. : Bone cell biology: The regulation of development, structure, and function in the skeleton. Am. J. Anat. $183: 1 \sim 44,1988$.

30）小澤英浩, 江尻貞一, 中村浩彰：骨吸収の細胞生物 学。蛋白質 核酸 酵素 40：492～505， 1995.

31) Sato, M. and Grasser, W.: Effects of bisphos- 
phonates on isolated rat osteoclasts as examined by reflected light microscopy. J. Bone Miner. Res. 5: 31 40, 1990.

32) Sato, M., Grasser, W., Endo, N., Akins, R., Simmons, H., Thompson, D. D., Golub, E. and Rodan, A. : Bisphosphonate action alendronate localiza- tion in rat bone and effects osteoclast ultrastructure. J. Clin. Invest. $88: 2095 \sim 2105,1991$.

33) Chambers, T. J. and Magnus, C. J. : Calcitonin alters behaviour of isolated osteoclasts. J. Pathol. $136: 27 \sim 39,1982$. 